\title{
Occupational Health Safety Effect on Hospital Safety
}

\author{
H. SOYAL*, M. SARIHAn AND O. YARAR \\ Okan University, Vocational School of Health Services, Istanbul, Turkey
}

\begin{abstract}
Operations around regulations of occupational health and safety in any sector of industry turn out to be quickly processed. In this paper, we have focused on this aspect in the health sector. Particular attention was drawn on occupational health and safety including occupational safety and accidents at work, and the factors distorting the hospital security. Instead of a detailed examination of occupational health and safety or the relevant regulations, the hospital staff were consulted to shed light on safety issues. With the participation of hospital staff survey data were obtained. Any differences due to demographic properties were investigated using data analysis.
\end{abstract}

DOI: 10.12693/APhysPolA.137.579

PACS/topics: Occupational health and safety, hospital staff, hospital security

\section{Introduction}

Work security is defined as the protection of workers from conditions which may have adverse effects on their health, due to hazards of the work. The definition includes also systematic studies to improve the working environment [1]. The protection of workers with occupational safety is aimed at ensuring the security of the services and institutions. The essential and main purpose of the job security, however, is to protect the workers. It is required to ensure a safe working environment, to protect employees from the negative effects of the workplace, maintaining the somatopsychic integrity by protecting them against work accidents and professional diseases $[2,3]$. National Institute for Occupational Safety and Health of the United States defines a healthy and secure hospital environment as the absence of physical, chemical, biological, ergonomic, mechanical dangers related to the work, occupational diseases caused by these dangers and risks and work accidents $[5,6]$. However, the employees in hospitals face several risks, dangers, accidents, and occupational diseases caused by infections, drugs, the dangers of materials, waste, lack of ergonomic design, operating conditions, equipment failure, excess workload, and careless behavior of employees $[7,8]$. Several studies have shown that due to failure of protection, doctors, nurses and other personnel suffer injuries or job accidents in the forms of mechanical (waste, etc.), chemical (disinfectants, etc.), biological (viruses, etc.), and physical (stinging, etc.) injuries [4, 9-14]. Moreover, they suffer from infectious diseases such as AIDS, hepatitis, skin diseases such as dermatitis, and vascular diseases such as varicose veins $[15,18,19]$. Joint Commission International and the services dealing with interests of the Ministry of Health quality standards, have issued safety notification for patients and employees. These criteria in the issued regulation regarding activities provided in hospital

*corresponding author; e-mail: aydefen@gmail.com are important because they allow for legal and institutional arrangements guaranteeing safety at work [20-24].

\section{Means and methods}

The model was developed to investigate the effects of factors like management expectations (ME), organizational learning (OL), overall perception of patient safety $(\mathrm{OP})$, team work in unit (TWU), teamwork units (TU), reporting frequency (rf), communication $(\mathrm{CO})$, feedback $(\mathrm{CO})$, management support (MS), and no punishment (NR). The descriptive research model, which is used extensively in the literature, was utilized in this study. The conditions, variables, and the relationship between variables associated with a new problem were examined. In this paper, information coming from hospital staff on occupational health and safety issues have been evaluated. Research was conducted with the employees of four different hospitals in the Istanbul region which formed domain of our research. It was assumed that hospital employees perceive measurement tools correctly, and they respond in an impartial, sincere, and realistic manner. A total of 850 questionnaires were distributed for the research. The sample was generated on 770 staffs who accepted the invitation to interview. This sample size, with $\pm 5 \%$ acceptable error rate, and 95\% confidence level meets the recommended sample magnitude.

\section{The findings and discussion}

In order to obtain reliable results and draw valid conclusions, the scale of investigated aspects had to be enough broad. Cronbach's Alpha model was used for the analysis. The results are shown in Table I. It turned out, that the Hospital Safety Scale (HSS) is at "high reliability" level because it was evaluated as overall score (0.814). Comparing to it other sub results, they seem to be quite good measure since their reliability is at a reliable level. It concerns the TWU, ME, OL, OP, MS, TU, NR, SF, and FB classes. Only the level of reliability in $\mathrm{CO}$ and $\mathrm{RF}$ classes is low. 
TABLE I

Hospital Safety Scale (HSS) sub and overall reliability criterion

\begin{tabular}{l|c}
\hline \hline & $\begin{array}{c}\text { Cronbach's } \\
\text { Alpha }\end{array}$ \\
\hline TWU (team work in unit) & 0.745 \\
ME (management expectations) & 0.764 \\
OL (organizational learning) & 0.777 \\
OP (overall perception of patient safety) & 0.701 \\
MS (management support) & 0.688 \\
TU (teamwork units) & 0.641 \\
HT (assignment) & - \\
CO (communication) & 0.512 \\
NP (no. punishment) & 0.624 \\
RF (reporting frequency) & 0.557 \\
NER (number of event reported) & - \\
SF (staff) & 0.715 \\
PSR (patient safety rating) & - \\
FB (feed back) & 0.729 \\
Total HSS & 0.814
\end{tabular}

Demographic characterization of participants involved in measurements is shown in Table II.

Based on correlation analysis performed in Table III, one can notice a significant positive relation between $\mathrm{Pa}$ tient Safety Rating (PSR) and TWU (0.41), ME (0.18), OP (0.23), CO (0.24), and RF (0.36). PSR increases when all those variables increase. There is a positive relationship between $\mathrm{ME}(0.22)$, TU (0.14), FB (0.24), and RF (0.15) with the NER. When these variables increase, the NER increases as well. There is no relationship between other variables and the NER.

Results shown in Table IV were obtained by the simple regression analysis in which PSR variable was taken as the independent variable. However, the other variables were individually determined as independent variables.
Regarding the disclosure rates $R^{2}$ of describing PSR variable, the best for it is OP variable. It allows to describe the change in the PSR variable by $25.6 \%$. If the OP increases by 1 point, PSR (Patient Safety Rating) increases by 0.556 . Variables NR and NER are not enough efficient in explaining the PSR variable.

TABLE II

Demographic characteristics of participants, where $n$ means number of participants of each class.

\begin{tabular}{|c|c|c|c|}
\hline & & $\mathrm{n}$ & {$[\%]$} \\
\hline \multirow{2}{*}{ gender } & male & 359 & 46.62 \\
\hline & female & 411 & 53.38 \\
\hline \multirow{5}{*}{ age } & $20-29$ & 195 & 25.32 \\
\hline & 30-39 & 288 & 37.48 \\
\hline & $40-49$ & 201 & 26.10 \\
\hline & $50-59$ & 77 & 10.00 \\
\hline & $>60$ & 9 & 1.10 \\
\hline \multirow{2}{*}{ marital status } & married & 516 & 67.01 \\
\hline & single & 254 & 32.99 \\
\hline \multirow{5}{*}{$\begin{array}{l}\text { How long have } \\
\text { you been working } \\
\text { in the hospital? }\end{array}$} & $<1$ year & 124 & 16.12 \\
\hline & $1-5$ years & 294 & 38.18 \\
\hline & $6-10$ years & 231 & 30.00 \\
\hline & $11-15$ years & 94 & 12.20 \\
\hline & $>16$ years & 27 & 3.50 \\
\hline \multirow{5}{*}{$\begin{array}{c}\text { How many } \\
\text { hours per week } \\
\text { do you work } \\
\text { on average? }\end{array}$} & $<20 \mathrm{~h}$ & 27 & 3.50 \\
\hline & 20-39 h & 68 & 8.83 \\
\hline & $40-59 \mathrm{~h}$ & 456 & 59.22 \\
\hline & $60-79 \mathrm{~h}$ & 175 & 22.73 \\
\hline & $>80 \mathrm{~h}$ & 44 & 5.75 \\
\hline \multirow{5}{*}{$\begin{array}{l}\text { What is your } \\
\text { working position } \\
\text { at the hospital? }\end{array}$} & doctor & 98 & 12.72 \\
\hline & nurse & 311 & 40.38 \\
\hline & manager & 209 & 27.14 \\
\hline & technician & 121 & 15.71 \\
\hline & other employees & 31 & 4.02 \\
\hline \multirow{2}{*}{$\begin{array}{l}\text { Are you directly } \\
\text { in contact } \\
\text { with the patient? }\end{array}$} & Yes & 665 & 86.36 \\
\hline & No & 105 & 13.64 \\
\hline
\end{tabular}

Correlation analysis between the variables used in the research.

TABLE III

\begin{tabular}{c|c|c|c|c|c|c|c|c|c|c|c|c}
\hline \hline & TWU & ME & OL & OP & MS & TU & CO & RF & FB & SF & PSR & NER \\
\hline TWU & 1 & & & & & & & & & & \\
ME & $0.45^{a}$ & 1 & & & & & & & & \\
OL & $0.66^{a}$ & $0.45^{a}$ & 1 & & & & & & & \\
OP & $0.32^{a}$ & $0.49^{a}$ & $0.14^{a}$ & 1 & & & & & & \\
MS & $0.52^{b}$ & $0.48^{a}$ & $0.25^{a}$ & $0.66^{a}$ & 1 & & & & & \\
TU & $0.46^{a}$ & $0.46^{a}$ & $0.19^{a}$ & $0.51^{a}$ & $0.44^{a}$ & 1 & & & & \\
CO & $0.14^{a}$ & $0.51^{a}$ & $0.11^{a}$ & $0.17^{a}$ & $0.39^{a}$ & $0.33^{a}$ & 1 & & & \\
RF & $0.12^{a}$ & $0.13^{a}$ & $0.32^{a}$ & $0.48^{a}$ & $0.21^{a}$ & $0.16^{a}$ & $0.21^{a}$ & 1 & & & \\
FB & $0.22^{a}$ & $0.19^{a}$ & $0.41^{a}$ & $0.25^{a}$ & $0.36^{a}$ & $0.51^{a}$ & $0.18^{a}$ & 0.09 & 1 & & \\
SF & $0.37^{a}$ & $0.25^{a}$ & $0.17^{a}$ & $0.33^{a}$ & $0.22^{a}$ & $0.23^{a}$ & $0.31^{a}$ & $0.10^{a}$ & $0.32^{a}$ & 1 & & \\
$\mathrm{PSR}$ & $0.41^{a}$ & $0.18^{a}$ & 0.11 & $0.23^{a}$ & 0.19 & 0.31 & $0.24^{a}$ & 0.36 & $0.16^{a}$ & 0.03 & 1 \\
$\mathrm{NER}$ & 0 & $0.22^{a}$ & 0 & 0.16 & 0.23 & $0.14^{a}$ & 0.11 & $0.15^{a}$ & $0.24^{a}$ & 0 & 0.01 & \\
\hline
\end{tabular}

${ }^{a} p<0.05,{ }^{b} p<0.01$ 
Single independent variables affecting the PSR variable.

TABLE IV

\begin{tabular}{c|c|c|c|c|c|c}
\hline \hline \multirow{2}{*}{ Model } & \multicolumn{2}{|c|}{$\begin{array}{c}\text { Non-standardized } \\
\text { coefficients }\end{array}$} & $\begin{array}{c}\text { Standardized } \\
\text { coefficients }\end{array}$ & $t$ & $p$ & \multirow{2}{*}{$R^{2}[\%]$} \\
\cline { 2 - 4 } & Beta & Std. Hata & Beta & & & \\
\hline TWU & 0.398 & 0.055 & 0.366 & 6.003 & $0.000^{a}$ & 16.10 \\
ME & 0.215 & 0.046 & 0.241 & 8.882 & $0.000^{a}$ & 5.90 \\
OL & 0.496 & 0.039 & 0.424 & 3.214 & $0.000^{a}$ & 12.30 \\
OP & 0.556 & 0.053 & 0.478 & 10.985 & $0.000^{a}$ & 25.60 \\
MS & 0.343 & 0.027 & 0.345 & 7.572 & $0.000^{a}$ & 8.80 \\
TU & 0.291 & 0.018 & 0.302 & 6.761 & $0.000^{a}$ & 12.60 \\
HT & 0.223 & 0.076 & 0.235 & 5.015 & $0.000^{a}$ & 6.70 \\
CO & 0.468 & 0.061 & 0.487 & 6.977 & $0.000^{a}$ & 6.40 \\
FB & 0.361 & 0.064 & 0.392 & 5.412 & $0.000^{a}$ & 7.10 \\
FE & 0.182 & 0.052 & 0.212 & 5.634 & $0.000^{a}$ & 6.80 \\
NER & 0.007 & 0.033 & 0.011 & 0.142 & 0.319 & - \\
SF & 0.211 & 0.024 & 0.232 & 3.294 & 0.01 & 2.60 \\
NR & 0.046 & 0.012 & 0.038 & 0.741 & 0.734 & - \\
\hline
\end{tabular}

${ }^{a} p<0.01$

\section{Conclusions}

Nowadays, full quality control and inspections in healthcare institutions or involved organizations, are supervised and controlled by the Ministry of Health. In some sense, these active inspections are intended to provide the hospital's occupational health and safety. However, these actions are not enough. We have analyzed these problem in private and noticed that the occupational health and safety legislation alone, do not provide security or safety in the hospital workplace. From this perspective the solution would be participation of employees in the processes of occupational health and safety, e.g., by sharing the ideas on the subject to change present situation. The context of our studies concerned in particular this problem. In fact, results of the research showed that, when hospital administrators include health workers in the occupational health and safety processes, security of the hospital becomes positively affected.

\section{References}

[1] E. Dizdar, Occupational safety, ABP Publishing and Printing, Ankara 2002, p. 98.

[2] Z. Sabuncuoglu, Human Resources Management, Ezgi Bookstore, Bursa 2000, p. 263.

[3] T. Source, Z. Adal, İ Ataay, et al., Human Resources Management, Dönence Printing and Publishing Services, Istanbul 1998, p. 396.

[4] N.A.C. Abdullah, J.T. Spickett, K.B. Rumckev, S.S. Dhaliwal, Int. Rev. Bus. Res. Pap. 5, 111 (2009).

[5] L. Khorshid, Y. Demir, Ergonomics and Nursing Hospital Management 10, 67 (2006).
[6] Özkan Ö, in: Health, Safety of Health Workers and Workplace Organization Unit. 2, National Health Workers Health Congress, Ankara 2001, p. 50.

[7] G. Bektş, E. Worker, M. Harroglu, in: Hospital Management 2005.

[8] N. Bahçecik, H. Öztürk, Colleguim Antropologicum 33, 1205 (2009).

[9] M. ilmaz, Health and Soc. 13, 30 (2003).

[10] İ. Dindar, H. Issever, M. Ozen, J. Nursing Forum 7, 59 (2004).

[11] İ. Dindar, H. Issever, M. Ozen, J. Nursing Forum 8, 18 (2005).

[12] TL. Zontek, Ph.D. thesis, University of Nebraska, 2006.

[13] J.A. Owens, J. Perinat. Neonat. Nursing 21, 92 (2007).

[14] S.P. Clarke, M. Schubert, T. Korner, Infec. Control Hosp. Epidemiol. 28, 473 (2007).

[15] N. Kaçmaz, Nursing Bulletin 12, 97 (1999).

[16] C. Aslan, E. Küçükkılınç, B. Tekgüz, et al., in: International Congress on Performance and Quality in Health Proceedings, Ankara 2009, p. 34.

[17] A. Atasoy, S. Aksoy, in: International Congress on Performance and Quality in Health Proceedings, Ankara 2009, p. 110.

[18] P. Bi, P. Tully, J.S. Pearce, et al., Epidemiol. Infect. 134, 465 (2006).

[19] K.A. Rios, D.A. Barbosa, A.G.S. Belasco, Rev. Latina. Americana de Enfermagem 18, 413 (2010).

[20] G. Waehrer, L. PJ, T.R. Miller, Int. J. Health Serv. 35, 343 (2005).

[21] Joint Commision International Accreditation Standards For Hospitals, Standarts Lists Version. USA: Joint Commision International, 2010, p. 193. 
[22] H. Guler, A. Ozturk, S.H. Kapan, et al., Standards of Service in Hospitals Eds. A. Cinal, M. Demir, Ministry of Health General Directorate of Treatment Services Department of Performance Management and Quality Improvement, Ankara 2011, p. 4.

[23] "Communiqué on Procedures and Principles Regarding Ensuring and Protecting Patient and Employee Safety in Health Institutions and Organizations", Official Gazette, Issue 27214, April 29, 2009.

[24] H. Öztürk, E. Babacan, E. Anahar, Gümüşhane Univer. J. Health Sci. 1, (4) (2012).

[25] "Regulation on Ensuring Patient and Employee Safety", Official Gazette, Issue 2789, April 6, 2011. 